\title{
Dampak RUU Akuntan Publik Terhadap Pengembangan Profesi Akuntan Publik Di Indonesia
}

\author{
Oleh \\ Indarto Waluyo ${ }^{1}$
}

\begin{abstract}
Abstrak
Profesi Akuntan Publik merupakan suatu profesi yang jasa utamanya adalah jasa assuran dan hasil pekerjaannya digunakan secara luas oleh publik sebagai salah satu pertimbangan penting dalam pengambilan keputusan ekonomis. Dengan demikian, profesi Akuntan Publik memiliki peranan yang sangat besar dalam mendukung terwujudnya perekonomian yang sehat, efisien dan transparan. Untuk melindungi kepentingan masyarakat dan sekaligus melindungi profesi Akuntan Publik, maka diperlukan suatu undang-undang yang mengatur praktik profesi Akuntan Publik. Pengaturan mengenai praktik profesi Akuntan Publik dalam Undang-Undang Nomor 34 tahun 1954 tidak sesuai lagi dengan perkembangan yang ada saat ini. Oleh karena itu disusunlah Rencana Undang-Undang baru tentang Praktik Akuntan Publik yang mengatur berbagai hal mendasar dalam praktik profesi Akuntan Publik.

Dalam penyusunan Rancangan Undang Undang baru tersebut ada beberapa hal yang krusial yang dikhawatirkan akan berpengaruh terhadap pengembangan profesi Akuntan Publik di Indonesia. Hal tersebut adalah ; 1) Sanksi pidana bagi Akuntan Publik, 2) Perijinan Akuntan Publik Asing, 3) Persyaratan Akuntan Publik.

Ketiga hal tersebut mendapat reaksi keras dari kalangan profesi maupun akademisi. Pertama, sanksi pidana dikhawatirkan akan semakin mengurangi minat generasi muda untuk terjun menjadi Akuntan publik yang saat ini sudah sangat rendah, sanksi administratif kiranya sudah cukup memadai. Kedua, perijinan Akuntan Publik Asing yang dirasa begitu mudah, akan menggusur keberadaan Akuntan Publik lokal. Hal ini dimungkinkan karena jumlah Akuntan Publik di beberapa negara ASEAN sangat banyak, sehingga meraka akan melakukan ekspansi ke Indonesia, disamping itu adanya potensi ancaman terhadap kepentingan keamanan negara ketika Akuntan Publik Asing tersebut memeriksa industri strategis negara. Ketiga, persayaratan untuk menjadi Akuntan Publik begitu mudah, karena tidak mensyaratkan harus dari jurusan akuntansi, hal ini menjadi preseden buruk bagi pengembangan jurusan akuntansi di Indonesia'
\end{abstract}

Kata kunci : RUU Akuntan Publik, Pengembangan Profesi Akuntan Publik

\section{Latar Belakang}

Akuntan Publik merupakan salah satu dari sekian profesi yang ikut mendukung perkembangan perekonomian. Profesi ini sangat berperan dalam peningkatan kualitas dan kredibilitas informasi keuangan suatu entitas. Dalam era liberalisasi seperti sekarang ini terjadi peningkatan kebutuhan akan jasa Akuntan Publik yang sangat besar, mulai dari entitas yang berorientasi laba (perusahaan) sampai entitas nir laba (LSM), mulai dari entitas yang menggunakan standar akuntansi keuangan komersial (SAK) sampai entitas yang menggunakan standar akuntansi pemerintah (SAP). Dengan demikian, Akuntan Publik

\footnotetext{
${ }^{1}$ Dosen Jurusan Pendidikan Akuntansi - Universitas Negeri Yogyakarta
} 
dituntut untuk senantiasa meningkatkan kompetensi dan profesionalisme, sehingga dapat memenuhi kebutuhan pengguna jasa dan mengemban kepercayaan publik dengan baik.

Untuk melindungi kepentingan masyaraka pengguna dan juga profesi Akuntan Publik itu sendiri dalam pemberian jasa, maka diperlukan adanya seperangkat undang-undang yang mengatur profesi Akuntan Publik, Undang-Undang yang ada saat ini yaitu Undang-Undang Nomor. 34 Tahun 1954 tentang Pemakaian Gelar Akuntan, dinilai sudah tidak sesuai lagi dengan perkembangan yang ada pada saat ini dan tidak mengatur hal-hal yang mendasar bagi profesi Akuntan Publik.

Keistimewaan dari Rencana Undang-Undang Akuntan Publik ini, yaitu mengatur mengenai "Jasa Asuran" yang merupakan hak ekslusif bagi Akuntan Publik, yaitu jasa Akuntan Publik yang bertujuan untuk memberikan keyakinan bagi pengguna atas hasil evaluasi atau pengukuran informasi keuangan dan non keuangan berdasarkan suatu kriteria. Selain mengatur mengenai profesi Akuntan Publik, Undang-Undang ini juga mengatur mengenai Kantor Akuntan Publik ( KAP ) yang merupakan wadah bagi Akuntan Publik dan bentuk usaha KAP yang sesuai dengan profesi Akuntan publik, yaitu independensi dan tanggung jawab professional terhadap hasil pekerjaannya. (www.ristek .go.id)

Adapun substansi rancangan RUU tersebut adalah sebagai berikut : Tujuan Undang Undang Akuntan Publik; Ketentuan Umum; Regulator Profesi; Asosiasi Profesi; Jasa Akuntan Publik dan Kantor Akuntan Publik; Bentuk Badan Usaha Kantor Akuntan Publik; Pendirian dan Pengelolaan Kantor Akuntan Publik; Perizinan Akuntan Publik dan Kantor Akuntan Publik; Penamaan Kantor Akuntan Publik; Kewajiban Akuntan Publik dan Kantor Akuntan Publik; Hak Akuntan Publik dan Kantor Akuntan Publik; Tanggungjawab Akuntan Publik dan Kantor Akuntan Publik; Daluwarsa Tuntutan Hukum; Larangan Akuntan Publik dan Kantor Akuntan Publik; Independensi; Pemeriksaan Akuntan Publik dan Kantor Akuntan Publik; Kerjasama Kantor Akuntan Publik dan Kantor Akuntan Publik Asing ; Sanksi Administratif dan Pidana; Ketentuan Perdata; Ketentuan Pidana atas Akuntan Publik, Kantor Akuntan Publik, Pihakk Terasosiasi.

Ada beberapa hal yang menarik dalam RUU tersebut :

- Dicantumkannnya sanksi pidana kepada Akuntan Publik

Pasal 63 ayat (1) mengatur tentang pengenaan sanksi pidana apabila akuntan publik melakukan atau terlibat atau memberikan keterangan palsu, dokumen palsu,manipulasi data

Pasal 63 ayat (2) mengatur tentang pengenaan sanksi pidana kepada akuntan publik yang tidak mematuhi standar profesi akuntan publik dan ketentuan lainnya dan merugikan bagi pihak lain

- Perijinan Akuntan Publik Asing

Pasal 7 dan Pasal 13 ayat (4) mengatur tentang akuntan publik asing, yang mana menempatkan akuntan publik asing mempunyai hak dan kewajiban yang sama termasuk dalam hal memperoleh klien di Indonesia, bahkan pengaturannya lebih mudah bila dibandingkan dengan akuntan publik lokal.

- Proses untuk menjadi Akuntan Publik

Proses menjadi Akuntan Publik disederhanakan dan basis calon Akuntan Publik diperluas, Dengan ketentuan tersebut berarati gelar CPA (certified public accountant) dapat diberikan kepada siapa saja yang lulus ujian CPA tanpa memandang dia lulusan jurusan apapun / tidak harus dari jurusan akuntansi.

\section{Dampak Terhadap Perkembangan Akuntan Publik}

Sebagaimana telah diumumkan oleh Pemerintah dan Dewan Perwakilan Rakyat Republik Indonesia (DPR RI) bahwa saat ini Komisi XI DPR RI telah mulai pembahasan terhadap 
RUU Akuntan Publik yang diajukan oleh Pemerintah kepada DPR RI dan RUU tersebut telah menjadi agenda Prolegnas Prioritas tahun 2010. UU Akuntan Publik akan menegaskan peran penting profesi akuntan publik di Negara ini dan melengkapi UU yang telah ada yang menyebutkan peranan akuntan publik, seperti :

- UU No. 34 th. 1954 tentang Pemakaian Gelar Akuntan, pasal 4;

- UU No. 11 th. 1992 tentang Dana Pensiun, pasal 52 (1);

- UU No. 1 th. 1995 tentang Perseroan Terbatas, pasal 59 (1);

- UU No 8 th. 1995 tentang Pasar Modal, pasal 64 (1) dan pasal 66;

- UU No. 10 th. 1998 tentang Perbankan, pasal 31A;

- UU No. 23 th. 1999 tentang BI, penjelasan pasal 30 (1);

- UU No. 12 th. 2008 tentang Dana Kampanye

Terdapat beberapa hal yang krusial dalam RUU Akuntan Publik tersebut, yang mempunyai dampak cukup luas terhadap pengembangan profesi akuntansi di Indonesia. Adapun hal krusial tersebut adalah :

\section{Sanksi pidana kepada Akuntan Publik}

Pasal 63 ayat (1) mengatur tentang pengenaan sanksi pidana apabila akuntan publik melakukan atau terlibat atau memberikan keterangan palsu, dokumen palsu,manipulasi data, sedangkan pasal 63 ayat (2) mengatur tentang pengenaan sanksi pidana kepada akuntan publik yang tidak mematuhi standar profesi akuntan publik dan ketentuan lainnya dan merugikan bagi pihak lain.

Ikatan profesi, seperti dalam press release (IAPI:2010) sangat keberatan terhadap ketentuan dalam pasal 63 ayat (1) karena perbuatan-perbuatan tersebut telah diatur dalam KUHP, sehingga akan berdampak munculnya duplikasi aturan, tumpang tindih, dan berpotensi menimbulkan perbedaan interpretasi atas suatu permasalahan sehingga menimbulkan ketidakpastian.

Juga terhadap pasal 63 ayat (2), karena tidak sesuai dengan karakteristik profesi akuntan publik dan beberapa alasan lainnya, yaitu:

1. Bahwa seorang akuntan publik bukanlah kuasi Negara, kuasi Pemerintah, atau pejabat publik yang diberikan kewenangan atas nama publik atau Negara sehingga produk akuntan publik bukan merupakan legal binding sehingga tidak sebanding apabila dikenakan sanksi pidana.

2. Bahwa produk dari pekerjaan akuntan publik adalah suatu opini atau pendapat akuntan publik terhadap suatu laporan keuangan atau informasi keuangan dimana opini tersebut merupakan suatu bentuk keyakinan memadai (reasonable assurance) dan bukan merupakan suatu pernyataan kebenaran absolut (mutlak) atas laporan keuangan atau informasi keuangan lainnya. Produk akuntan publik tersebut bukan akta otentik sebagaimana dikeluarkan oleh pejabat publik.

3. Bahwa standar profesi dan kode etik yang digunakan oleh akuntan publik adalah bukan merupakan produk hukum yang termasuk dalam jenis dan hirarki perundang-undangan sebagaimana dimaksud dalam UU No.10 Tahun 2004 tentang Pembentukan Perundangundangan karena standar profesi dan kode etik ditetapkan oleh asosiasi profesi.

4. Bahwa standar profesi akuntan publik adalah suatu acuan yang digunakan dalam menjalankan profesinya dimana dalam pelaksanaanya banyak menggunakan professional jugdement dan berbasis sampling, oleh karena itu pengaturannya berbeda dengan ketentuan hukum yang sifatnya pasti dan tidak menimbulkan keragu-keraguan.

5. Bahwa dengan adanya ketentuan tersebut dan sifat serta karakteristik jenis pekerjaan akuntan publik maka dikhawatirkan akan rawan timbulnya kriminalisasi terhadap profesi akuntan publik. 
Selain alasan tersebut, pengenaan sanksi pidana atas pekerjaan akuntan publik juga akan menimbulkan dampak meningkatnya risiko profesi dan bisnis akuntan publik sehingga akan mengurangi minat dan tidak mendorong pertumbuhan profesi akuntan publik yang sudah sangat rendah (tabel 1).

Profesi berpendapat bahwa atas ketidakpatuhan terhadap standar profesi dan kode etik cukup diatur melalui pengenaan sanksi profesi, yaitu pengenaan sanksi terhadap perizinan. Dalam Peraturan Menteri Keuangan nomor 17 tahun 2008 sudah diatur sanksi peringatan, pembekuan dan pencabutan terhadap perizinan akuntan publik.

Tabel 1 Pertumbuhan Akuntan Publik di Indonesia

\begin{tabular}{|c|c|c|}
\hline Tahun & Jumlah Akuntan Publik & Pertumbuhan \\
\hline 2006 & 889 & - \\
\hline 2007 & 893 & +4 \\
\hline 2008 & 877 & -16 \\
\hline 2009 & 903 & +26 \\
\hline 2010 & 918 & +13 \\
\hline
\end{tabular}

Sumber : PPAJP, Kemenkeu

\section{Perijinan Akuntan Publik Asing}

Ikatan profesi berkeberatan terhadap pengaturan akuntan publik asing sebagaimana diatur dalam Pasal 7 dan Pasal 13 ayat (4) RUU Akuntan Publik. Pengaturan akuntan publik asing tersebut lebih bersifat untuk mengakomodir kepentingan untuk memenuhi kesepakatan WTO dan kesepakatan liberalisasi jasa akuntansi dikawasan ASEAN 2015 sebagaimana telah ditandatanganinya "ASEAN MRA Framework on Accountancy Services" oleh Negaranegara ASEAN tahun 2008, daripada untuk memberikan perlindungan terhadap akuntan publik lokal (IAPI:2010).

Begitu RUU disyahkan, ratusan bahkan ribuan Akuntan Publik asing akan membanjiri Indonesia, lambat lain Akuntan Publik lokal akan menjadi minoritas dan akhirnya akan menjadi penonton di negeri sendiri, Hal ini dimungkinkan karena jumlah akuntan di negara tetangga sudah cukup banyak bila dibandingkan dengan Indonesia (tabel 2). Sungguh suatu hal yang memprihatinkan.

Tabel 2 Jumlah Akuntan Publik Di Beberapa Negara ASEAN

\begin{tabular}{|c|c|c|}
\hline Negara & Jumlah Penduduk & Jumlah Akuntan Publik \\
\hline Singapore & 5.000 .000 & 15.000 \\
\hline Philipina & 88.000 .000 & 15.000 \\
\hline Thailand & 66.000 .000 & 6.000 \\
\hline Malaysia & 25.000 .000 & 2.500 \\
\hline Vietnam & 85.000 .000 & 1.500 \\
\hline Indonesia & 230.000 .000 & 1.000 \\
\hline
\end{tabular}

Sumber : IAPI

Pengaturan dalam pasal-pasal tersebut menempatkan akuntan publik asing mempunyai hak dan kewajiban yang sama termasuk dalam kesempatan untuk mendapatkan klien-klien di Indonesia, bahkan pengaturannya lebih mudah dibandingkan dengan pengaturan akuntan publik lokal. Pengaturan demikian disamping akan menggusur keberadaan akuntan publik lokal juga dapat berpotensi menimbulkan ancaman terhadap kepentingan dan keamanan Negara. Akuntan publik asing dapat mengakses aspek strategis dan kerahasiaan Negara melalui pemberian jasa kepada instansi Pemerintah, BUMN, atau entitas strategis lainnya. Apalagi potensi tersebut akan bertambah ketika akuntan publik dapat melakukan audit atas 
laporan keuangan Pemerintah untuk dan atas nama BPK. Karena itu RUU ini kurang memberikan perlindungan terhadap keselamatan Negara. Selain itu RUU ini juga tidak mengantisipasi bagaimana bentuk tanggung jawab hukum terhadap akuntan publik asing, mengingat sesuai Pasal 38 RUU Akuntan Publik disebutkan bahwa akuntan publik (sebagai individu) bertanggung jawab atas jasa yang diberikan. Pengaturan demikian akan menimbulkan permasalahan pada saat akuntan publik asing sudah tidak berdomisili atau keluar dari Indonesia, namun terdapat suatu kasus yang melibatkan akuntan asing tersebut. (IAPI:2010)

\section{Proses untuk menjadi Akuntan Publik}

Proses menjadi Akuntan Publik disederhanakan dan basis calon Akuntan Publik diperluas, Dengan ketentuan tersebut berarati gelar CPA (certified public accountant) dapat diberikan kepada siapa saja yang lulus ujian CPA tanpa memandang dia lulusan jurusan apapun (tidak harus dari jurusan akuntansi). Gambar 1

Rencana Undang-Undang ini juga mendapat reaksi sangat keras dari kalangan perguruan tinggi dan akademisi. Salah satunya dari Prof. Dr. Muslich Anshori (Dekan Fakultas Ekonomi Universitas Airlangga) yang mengatakan bahwa "Apakah hanya sebegitu mudahnya menjadi akuntan (publik)", meskipun ada mekanisme penambahan 8 SKS untuk jurusan akuntansi, 12 SKS untuk jurusan ekonomi, dan 16 SKS untuk jurusan studi lain. Harusnya RUU mengakomodir bagaimana profesi akuntansi ini bisa menarik minat para sarjana akuntansi untuk terjun menekuninya. 


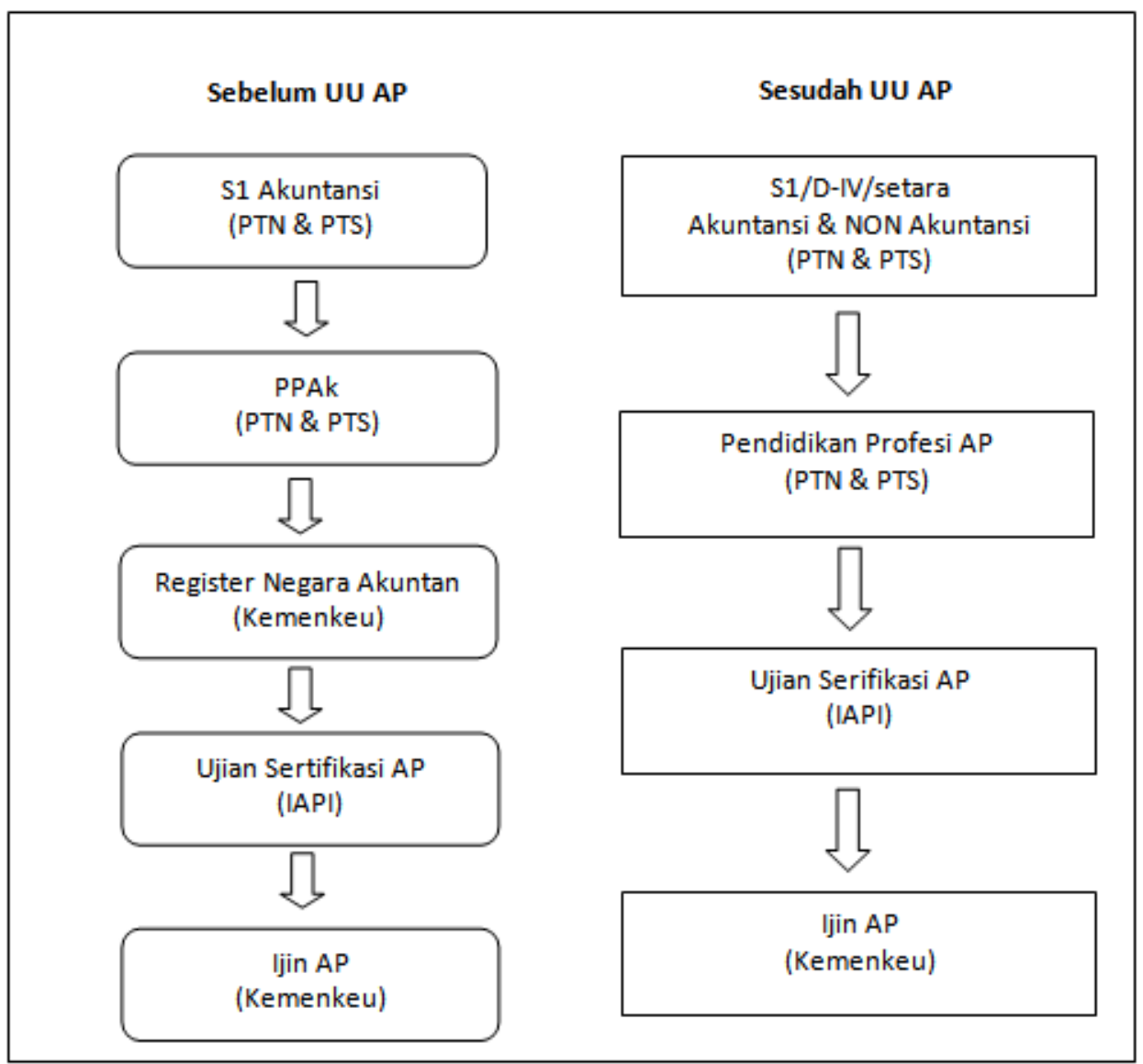

Sumber: PPAJP, Kemenkeu

Gambar 1. Proses Menjadi AP

\section{Simpulan}

Profesi Akuntan Publik memiliki peranan yang sangat besar dalam mendukung terwujudnya perekonomian yang sehat, efisien dan transparan. Peranan Akuntan Publik tersebut terutama dalam peningkatan kualitas dan kredibilitas informasi keuangan atau laporan keuangan suatu entitas. Dalam hal ini Akuntan Publik mengemban kepercayaan masyarakat untuk memberikan opini atas laporan keuangan suatu entitas. Sebagai salah satu profesi pendukung kegiatan dunia usaha,dalam era liberalisasi perdagangan dan jasa, kebutuhan pengguna jasa Akuntan Publik akan semakin meningkat, terutama kebutuhan atas kualitas informasi keuangan yang digunakan sebagai salah satu pertimbangan dalam pengambilan keputusan ekonomis.

Untuk melindungi kepentingan masyarakat dan sekaligus melindungi profesi Akuntan Publik, maka diperlukan suatu undang-undang yang mengatur praktik profesi Akuntan Publik. Sampai saat terbentuknya Undang-Undang ini, di Indonesia belum ada undangundang yang khusus mengatur mengenai praktik profesi Akuntan Publik. Undang-undang yang saat ini ada dan masih berlaku adalah Undang-Undang Nomor 34 tahun 1954 tentang Pemakaian Gelar Akuntan. Pengaturan mengenai praktik profesi Akuntan Publik dalam Undang-Undang Nomor 34 tahun 1954 tidak sesuai lagi dengan perkembangan yang ada saat ini,karena Undang-Undang Nomor 34 tahun 1954 tidak mengatur hal-hal yang mendasar dalam praktik profesi Akuntan Publik. Oleh karena itu disusunlah Undang-Undang tentang Praktik Akuntan Publik yang mengatur berbagai hal mendasar dalam praktik profesi Akuntan Publik. Undang-Undang ini disusun dengan tujuan untuk melindungi kepentingan publik, mendukung perekonomian yang sehat, efisien dan transparan, memelihara integritas profesi 
Akuntan Publik, serta melindungi kepentingan profesi Akuntan Publik sesuai dengan standar dan kode etik profesi.

Namun demikian, dalam penyusunan Rencana Undang Undang Akuntan Publik ditenui adanya pasal-pasal krusial yang dikhawatirkan akan berdampak buruk bagi pengembangan akuntansi di Indonesia. Pasal pasal krusial tersebut antara lain : pasal 63 ayat 1 dan ayat 2 mengenai sanksi pidana bagi Akuntan Publik, hal ini dikhawatirkan semakain mengurangi minat generasi muda untuk terjun menjadi Akuntan publik yang saat ini sudah sangat rendah.

Pasal 7 dan Pasal 13 ayat (4) tentang perijinan Akuntan Publik Asing yang dirasa begitu mudah, akan menggusur keberadaan Akuntan Publik lokal. Hal ini dimungkinkan karena jumlah Akuntan Publik di beberapa negara ASEAN sangat banyak, sehingga meraka akan melakukan ekspansi ke Indonesia, disamping itu adanya potensi ancaman terhadap kepentingan keamanan negara ketika Akuntan Publik Asing tersebut memeriksa industri strategis negara.

Pasal krusial lain adalah persayaratan untuk menjadi Akuntan Publik begitu mudah, karena tidak mensyaratkan harus dari jurusan akuntansi, hal ini menjadi preseden buruk bagi pengembangan jurusan akuntansi di Indonesia'

\section{Daftar Pustaka}

Agus Suparto. (2010). "Sosialisai Profesi Akuntan Publik". Seminar Sosialisai Profesi Akuntan Publik dan Perkembangan Standar Akuntansi Terkini. Yogyakarta. PPAJP Kemenkeu.

Institut Akuntan Publik Indonesia. (2010). "IAPI Menolak Materi RUU Akuntan Publik". Press Release. Jakarta.

. (2010). Rancangan Undang Undang Akuntan Publik. Jakarta.

.(2010). Penjelasan Rancangan Undang Undang Akuntan Publik. Jakarta.

http://www.ristek.go.id/index.php/module/News+News/id/9055

http://www.djlk.depkeu.go.id/dpajp/data/RUUAP.pdf 